\title{
Benznidazole affects expression of Th1, Th17 and Treg cytokines during acute experimental Trypanosoma cruzi infection
}

\author{
Mariana Gatto ${ }^{1 *}$, Larissa Ragozo Cardoso Oliveira², Fernanda De Nuzzi Dias³, João Pessoa Araújo Júnior², \\ Carlos Roberto Gonçalves Lima', Eliana Peresi Lordelo ${ }^{4}$, Rodrigo Mattos dos Santos ${ }^{1}$ and Cilmery Suemi Kurokawa ${ }^{1}$
}

\begin{abstract}
Background: The present study evaluated the effect of treatment with benznidazole on mRNA expression of IFN- $\gamma$, IL17, IL-10, TGF- $\beta$ and FoxP3 in spleen and heart tissue of BALB/c mice in the acute phase of an experimental infection with Trypanosoma cruzi, strains JLP or Y.

Methods: The mRNA expression of cytokines and parasite load were assessed by q-PCR. Dependent groups were compared using Student's paired t-test and independent groups were compared using Student's unpaired t-test.

Results: Infection with the JLP or $Y$ strains increased expression of IFN- $\gamma$ in the heart and of IL-10 and IL-17 in the spleen and heart compared to uninfected animals. Treatment increased the expression of IFN- $\gamma$ and decreased the expression of IL-17, IL-10, TGF- $\beta$ and Foxp3 in spleen and heart tissue compared to untreated infected animals.

Conclusion: Benznidazole can induce Th1 profile in the initial of the acute phase. The treatment decreased the parasite load in both organs, although the number of parasites in Y-strain-infected mice remained high. The data suggest that benznidazole may modulate cytokine expression in infection and can be dependent of the strain. However, treatment was not fully effective in the infection provoked by $Y$ strain, probably due to the characteristics of the strain itself.
\end{abstract}

Keywords: Chagas disease, Trypanosoma cruzi, Immune response, Cytokines, q-PCR

\section{Background}

Chagas disease $(C D)$, an endemic infection caused by the protozoan hemoflagellate Trypanosoma cruzi (T. cruzi), is a major public health problem in Latin America with nearly 10 million infected individuals while a further 25 million are considered at risk [1-5].

The acute phase of infection is usually subclinical and with nonspecific symptoms [6]. In this phase, there is deep parasitemia and the host immune system works to isolate T. cruzi in an attempt to avoid dissemination $[7,8]$. However, the inefficiency of the immune response in achieving complete elimination of the parasite ensures that T. cruzi persists in the host, which evolves to the chronic form of

\footnotetext{
* Correspondence: marianagatto11@hotmail.com

'Department of Tropical Diseases, Botucatu Medical School, São Paulo State University (UNESP - Univ Estadual Paulista), Av. Professor Mário Rubens Guimarães Montenegro, s/n, Distrito de Rubião Júnior, Botucatu 18.6186-87, SP, Brazil

Full list of author information is available at the end of the article
}

$\mathrm{CD}$ and may present different manifestations [9]. CD patients can remain years without developing clinical symptoms, thus characterizing the indeterminate phase of the disease or evolve to a symptomatic chronic phase with cardiac and/or digestive alterations [10-13]. Genetics, host immunity and parasite characteritics can result in different symptoms and clinical signs of CD $[6,14,15]$.

Acute phase parasitemia control and development of the chronic phase are probably the result of parasitehost interaction that involves the cooperative action between drug effects and the host immunological response $[16,17]$. Proinflammatory cytokine production, such as IL-12, IFN- $\gamma$ and TNF- $\alpha$, are required to activate T lymphocytes, macrophages and other cells, resulting in parasitemia control [7, 18-21]. Another cytokine that has been investigated in CD is IL-17. The IL-17 is related to protection, and high levels of this interleukin re- 
sult in decreased parasitemia and increased production of inflammatory cytokines such as IFN- $\gamma$, IL-6 and TNF$\alpha$ [22]. Furthermore, high IL-17 levels lead to less injury and lower mortality, a fact probably associated with its regulatory role in controlling the effects of other cytokines, such as IFN- $\gamma$ and IL-12 [23]. Despite the publication of some studies that assessed IL-17, its role in CD remains unclear.

In addition to the pathogen elimination, the effector immune response uses different regulatory mechanisms to reduce tissue damage caused by excessive inflammation [24]. One of these mechanisms is performed by a subset of $\mathrm{CD}^{+}{ }^{+} \mathrm{T}$ lymphocytes called regulatory $\mathrm{T}$ cells (Tregs), which produce TGF- $\beta$ and IL-10, and also express the $\mathrm{CD} 25$ receptor and the transcription factor Forkhead BoxP3 $\left(\mathrm{CD} 4{ }^{+} \mathrm{CD} 25^{+} \mathrm{Foxp}^{+}\right)$[25]. Tregs are able to modulate the immune response to self-epitopes, tumoral cells and pathogens; however, it can excessively supress the immune response and impair the resolution of infection [26, 27]. The exact role of Tregs in the Chagas disease, mainly during treatment, is still unclear. A study showed that patients with the indeterminate form of $\mathrm{CD}$ have an increased frequency of CD4 ${ }^{+} \mathrm{CD} 25^{\text {high }}$, which produces high IL-10 and TGF- $\beta$ levels, suggesting that Tregs contribute to the efficient control of parasite by effector cells without developing deleterious response and tissue lesions [28]. On the other hand, other studies have shown that Treg cells are not related to the immunopathogenesis of disease. Inactivation of Tregs cells resulted in low parasitemia and mortality of mice infected with $T$. cruzi, and did not affect the inflammatory response or frequency of $\mathrm{TCD}^{+}$cells in inflammatory foci $[29,30]$.

The treatment of $\mathrm{CD}$ is based on benznidazole (BZN), an effective drug during the acute and initial indeterminate chronic phases of infection and for congenital infection. However, its effectiveness in the phase of the disease is still unclear [31]. The drug can interfere directly in the synthesis of T. cruzi DNA, proteins and lipids, which facilitates the elimination of the parasite and affects iNOS gene expression, thus enhancing phagocytosis and modifying pro- and anti-inflammatory mediators to reduce the synthesis of IL-10, IL-1 $\beta$, IL- 6 and nitrite [32, 33]. The exact mechanism by which BZN acts remains unclear, but studies suggest that treatment in cooperation with the host immune system has a large impact on the clearance of parasites [17, 34].

Thus, we believe that the analysis of BZN treatment in relation to some aspects of the host immune response, such as pro- and anti-inflammatory cytokines, could better elucidate treatment impact on the acute phase of the infection by $T$. cruzi strains with different virulences. It would also provide a better understanding of the parasite-host interaction in $\mathrm{CD}$. Therefore, this study aimed to evaluate the effect of BNZ treatment on mRNA expression of IFN- $\gamma$, IL-17, IL-10, TGF- $\beta$ and Foxp3 in spleen and heart tissue of mice infected with either different strains of $T$. cruzi in the acute phase of $C D$ infection.

\section{Methods \\ Animals}

Eight to ten-week-old female BALB/c mice were obtained from the breeding colony of the Department of Tropical Diseases (UNESP). All animals received sterile water and food ad libitum throughout the experiment. All the procedures involving animals and their care were conducted in conformity with the national and international guidelines and were approved by the Animal Ethics Committee of the Botucatu Medical School of UNESP (protocol number: FMB-PE-85/2010, CEUA-854/10).

\section{T. cruzi strains}

Two different $T$. cruzi populations were used: the $\mathrm{Y}$ strain - considered highly virulent - and the JLP strain - isolated from a chronic chagasic patient treated at the Heart Institute of the School of Medicine of São Paulo University (USP). Both strains were kindly provided by Dr. Vicente Amato Neto, from the Tropical Medicine Institute of USP, and maintained at the Tropical Disease Research Laboratory of Botucatu Medical School (UNESP).

\section{Experimental groups}

Mice were separated into eight groups $(n=5)$, namely: G1 - control JLP (uninfected, untreated); G2 - treated control JLP (uninfected, treated with BZN); G3 - infected with JLP strain, untreated; G4 - infected with JLP strain and treated with BNZ; G5 - Y control (uninfected, untreated); G6 - treated control Y (uninfected, treated with BNZ); G7 - mice infected with Y strain, untreated; G8 - mice infected with the $\mathrm{Y}$ strain and treated with BNZ.

\section{T. cruzi infection}

The Y and JLP T. cruzi parasites were maintained in vivo through serially passages in BALB/c mice to ensure their virulence. Cardiac puncture was performed in previously infected animals and blood containing trypomastigotes was analized by optical microscopy. Parasite concentration was adjusted to $10^{4}$ parasites $/ \mathrm{mL}$ in Neubauer chamber and the final volume was adjusted with sterile buffered saline. Thus, $100 \mu \mathrm{L}$ of suspension containing metacyclic $\mathrm{Y}$ and JLP trypomastigotes forms from $T$. cruzi strains was inoculated intraperitoneally in experiment animals and distributed into groups G3, G4 (JLP) and G7, G8 (Y). Infection was using $5 \mu \mathrm{L}$ of caudal blood samples and examined by optical microscopy at 
the beginning and end of the acute phase of infection [35]. To undergo the same stress as the infected animals, control groups G1, G2, G5 and G6 were inoculated with $100 \mu \mathrm{L}$ of saline on day one of infection.

Parasitemia curves for Y and JLP T. cruzi strains used in the present study were previously defined by the research group. The $\mathrm{Y}$ strain is more virulent with an acute phase of 14 days and peak parasitemia at day 7 post-infection, whereas the JLP strain presents a 28-day acute phase and peak parasitemia at 14 days after infection [36].

\section{BNZ treatment}

During the acute phase of infection for each $T$. cruzi strain, mice were treated daily $(100 \mathrm{mg} / \mathrm{kg})$ with $\mathrm{BNZ}$ $\left(\right.$ Rochagan $\left.^{\circ}\right)$. BNZ pills were macerated and diluted in saline and each animal received the treatment by gavage. Animals infected with the JLP strain started treatment at day 7 post-infection (p.i.) and ended at day 28 p.i. (end of acute phase), thus lasting 22 days. Animals infected with the Y strain were treated from day 4 p.i. until day 14 p.i. (end of acute phase), totaling 11 days. Animals without infection and treated with BNZ (G2 JLP and G6 $\mathrm{Y})$ were treated by the same procedure as their respective infected groups. To promote the same stress level as BNZ-treated animals, the groups G1, G3, G5 and G7 started and followed treatment with $100 \mu \mathrm{L}$ of saline by gavage on the respective days of the $\mathrm{BNZ}$ treatment.

\section{Euthanasia of animals}

Mice of all groups of the JLP strain (G1, G2, G3 and G4) were euthanized after the end of the 22 days of treatment (day 29 p.i.) and animals of all groups of the $\mathrm{Y}$ strain (G5, G6, G7 and G8) were euthanized after 11 days of treatment (day 15 p.i.). Euthanasia was performed using an excessive dose $(0.2 \mathrm{~mL})$ of anesthetic (Hypnol ${ }^{\circ}$ $3 \%$, Syntec, Brazil) intraperitoneally.

\section{Cardiac and splenic parasitism by qPCR}

The spleen and heart were removed from mice 22 days after infection in groups G3 and G4, and 11 days after in G7 and G8. Total DNA was extracted from approximately $100 \mathrm{mg}$ of each organ by the phenol-chloroform isoamyl alcohol method (Life Technologies, USA). Afer tissue samples were frozen in liquid nitrogen, they received $1 \mathrm{~mL}$ of lysis buffer $(\mathrm{NaCl} 4 \mathrm{M}$; Tris- $\mathrm{HCl} \mathrm{pH}$ 7.5, $1 \mathrm{M}$; EDTA $0.5 \mathrm{M})$ and were crushed. Then, to the crushed mixture was added lysis buffer, proteinase K (InvitroGen, USA) and SDS $10 \%$ followed by overnight incubation in a water bath at $37{ }^{\circ} \mathrm{C}$. Next, the mixture received more proteinase $\mathrm{K}$ and was incubated for two hours in a water bath at $37{ }^{\circ} \mathrm{C}$. ANE buffer $5 \mathrm{X}$ (sodium acetate $1 \mathrm{M} ; \mathrm{NaCl} 4 \mathrm{M}$; EDTA $0.5 \mathrm{M}$; SDS 10\%) and phenol- chloroform isoamyl alcohol (25:24:1) (Life Technologies, USA) were added to the tubes and them centrifuged for $20 \mathrm{~min}$ at $5000 \mathrm{rpm}$ at $4{ }^{\circ} \mathrm{C}$. Supernatant was removed and transferred to another tube and the step described above was repeated. To the supernatant $10 \mathrm{~mL}$ of chloroform isoamyl alcohol at a 24:1 ratio (Life Technologies, USA) was added, which was centrifuged for $20 \mathrm{~min}$ at $5000 \mathrm{rpm}$ at $4{ }^{\circ} \mathrm{C}$. The supernatant was then transferred and supplemented with $\mathrm{NaCl} 4 \mathrm{M}$ and $20 \mathrm{~mL}$ of cold absolute ethanol (Sigma, USA). The tubes were maintained at $-20{ }^{\circ} \mathrm{C}$ overnight and then centrifuged for $45 \mathrm{~min}$ at $5000 \mathrm{rpm}$ at $4{ }^{\circ} \mathrm{C}$. The precipitate DNA was left at room temperature for two hours, dissolved in $250 \mu \mathrm{L}$ of sterile milli-Q water, diluted to $100 \mathrm{ng} /$ and stored at $-20{ }^{\circ} \mathrm{C}$. The DNA samples were read by spectrophotometer (NanoDrop, Thermo Scientific, USA) and only samples with $260 / 280$ ratio higher than 1.8 were utilized. Relative quantification of $T$. cruzi DNA was performed using a standard curve based method for relative real-time $\mathrm{PCR}$ data processing [37] with a 7300 real-time PCR Systems (Applied Biosystems, USA) and Maxima SYBR Green qPCR Master Mix (Thermo Scientific, USA) containing 100 ng of DNA.

Each quantitative PCR (q-PCR) reaction was set in duplicate in a total of $20 \mu \mathrm{L}$ each, which contained $0.2 \mathrm{mM}$ of each forward and reverse primer, $1 \mu \mathrm{L}$ of template gDNA, $10 \mu \mathrm{L}$ of qPCR master mix and $8.2 \mu \mathrm{L}$ nucleasefree water. In addition, a "no template" control in duplicate was included on each plate to prove that amplicon contamination was absent. PCR conditions were as follows: initial denaturation at $95{ }^{\circ} \mathrm{C}$ for $10 \mathrm{~min}$ and 40 cycles at $95{ }^{\circ} \mathrm{C}$ for $15 \mathrm{~s}$ and $60{ }^{\circ} \mathrm{C}$ for $60 \mathrm{~s}$. Amplification of specific products was confirmed by a single melting curve profile generated at the end of each run. Standard curves were constructed by a serial ten-fold dilution with the DNA of a positive control tissue infected with $T$. cruzi. This positive sample received the relative value of 100 and the concentrations in all other tissues were normalized proportionately. Quantitative real-time PCR DNA analyses were performed using T. cruzi primers sequences available in the GenBank database (Table 1).

\section{Gene expression of cytokines by RT-qPCR}

The spleen and heart were extracted from mice of groups G1, G2, G3 and G4 22 days after treatment (JLP strain) and from groups G5, G6, G7 and G8 11 days after treatment (Y strain). Approximately $100 \mathrm{mg}$ of each organ was stored in an RNASafer (Applied Biosystems, USA) and total RNA was extracted using the TRIZOL ${ }^{\circ}$ reagent (Invitrogen, Canada) according to the manufacturer's instructions. The concentration of total RNA was determined by the absorbance values of samples at 
Table 1 Primer sequences

\begin{tabular}{ll}
\hline Gene & Primer sequences \\
\hline IFN- $y$ & F 5'- AgA ggA Tgg TाT gCA TCT ggg TCA-3' \\
& R 5'- ACA ACg CTA TgC AgC TTg TTC gTg-3' \\
IL-17 & F 5'- ACC gCA ATg AAg ACC CTg AT-3' \\
& R 5'- TCC CTC CgC ATT gAC ACA-3' \\
IL-10 & F 5'- gCC AAg CCT TAT Cgg AAA Tg-3' \\
& R 5'- CAC CCA ggg AAT TCA AAT gC-3' \\
TGF- $\beta$ & F 5' - AAC AAT TCC Tgg CgT TAC CT - 3' \\
Foxp3 & R 5' - CTg CCg TAC AAC TCC AgT gA- 3' \\
& F 5'- CCC Agg AAA GAC AGC AAC CT -3' \\
GAPDH & R 5'- TTC TCA CCA CCA ggC CAC TTg -3' \\
& F 5' - CCT CgT CCC gTA gAC AAA ATg-3' \\
T. cruzi & R 5' - TgA Agg ggT CgT TgAT ggC-3' \\
& F- 5'-gCT CT gCC CAC AMg ggT gC-3' \\
& R- 5'-CCA AgC AgC ggA TAg TTC Agg-3'. \\
\hline
\end{tabular}

$260 \mathrm{~nm}$ and expressed as ng/ $\mu \mathrm{L}$. All samples showed absorbance of approximately 2.0. The cDNA was synthesized from $1 \mu \mathrm{g}$ of total RNA using reverse transcriptase (ImProm-II $^{\mathrm{TM}}$ Reverse Transcriptase System, Promega, USA). The reaction conditions were those described for DNA and primers used by Cezário et al. [38]. The relative concentration of IFN- $\gamma$, IL-17, IL-10, TGF- $\beta$ and Foxp3 was obtained as described above after normalization with GAPDH. Quantitative real-time PCR mRNA analyses were performed using murine primer sequences available in the GenBank database (Table 1).

\section{Statistical analysis}

Statistical analysis was accomplished using the Prism program v. 4.0. Dependent groups were compared using Student's paired t-test and independent groups were compared using Student's unpaired t-test. The significance level was set at $5 \%$ or the corresponding $p$-value.

\section{Results}

Treatment with BNZ reduces parasite load

Our initial objective was to evaluate the treatment effects on parasite load in the spleen and heart of mice infected with either Y or JLP strain during acute infection. In relation to JLP strain (Fig. 1a), treatment significantly decreased the number of $T$. cruzi DNA in spleen and heart (G4) (mean \pm SD: $1.893 \pm 0.6916$ and $0.59 \pm 0.503$ respectively) in comparison to spleen and heart of infected groups (G3) (1013 \pm 230.4 and $35.85 \pm 12.72$ respectively). Smilar results were observed in Y strain (Fig. 1b). BNZ treatment significantly decreased number of T. cruzi DNA in spleen and heart (G8) $(34,180 \pm 0.8229$ and 11,240 \pm 3473 respectively) in comparison to spleen and heart of infected groups (G7) $(79,520 \pm 9363$ and 35,360 \pm 4282 respectively). However, it was observed that infection with $\mathrm{Y}$ resulted in more parasites in spleen and heart when compared with the JLP strain (Fig. 1a). Although treatment significantly decreased the number of $T$. cruzi DNA infecting both strains, this number remained high in Y strain infection, both in the spleen and heart (Fig. 1b).

\section{Treatment with BNZ increases gene expression of IFN- $\gamma$ mRNA}

We assessed the effect of treatment on expression of this cytokine in the heart and spleen of animals infected with different strains of T. cruzi (Fig. 2). As to the spleen in JLP and Y strains, there was no significant difference among controls, treated and infected groups, but treatment significantly increased 1.9 -fold IFN- $\gamma$ mRNA in JLP infected/treated (G4) and 8.78-fold in Y infected/ treated (G8) in comparison to other groups (G1, G2, G3 and G5, G6, G7, respectively) (Figs. $2 \mathrm{a}$ and b). As for the heart, the groups infected with JLP strain (G3) expressed 5.9 -fold higher mRNA IFN- $\gamma(p<0.05)$ in relation to controls and treated groups (G1, G2). The BNZ treatmet (G4) increased 1.9-fold IFN- $\gamma$ mRNA in comparasion to G3 and 11.3-fold IFN- $\gamma$ mRNA in relation to G1 and G2 $(\mathrm{p}<0.05)$ (Fig. 2a). The group infected with Y strain (G7) showed increasement of 197-fold IFN- $\gamma$ mRNA $(\mathrm{p}<$ $0.05)$ when compared to G5 and G6. BNZ treatment (G8) increased significantly 1.26 -fold mRNA in relation to G7 and 248-fold ( $\mathrm{p}<0.05)$ in comparasion to G5 and G6 groups (Fig. 2b).
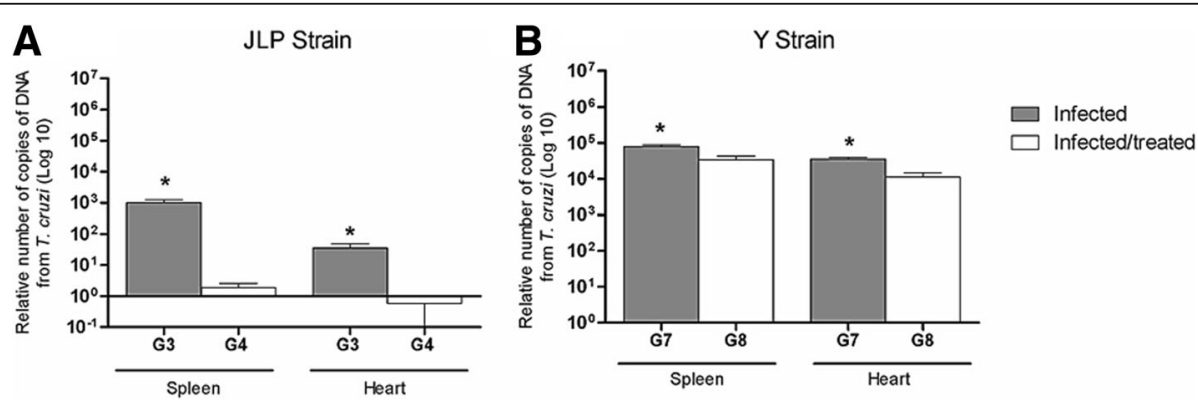

Fig. 1 Parasite load of T. cruzi. Parasite load (DNA of T. cruzi) in the spleen and heart of BALB/C mice $(n=5)$ during acute infection with (a) JLP and (b) Y strains. G3; infected-JLP mice, G7; infected-Y mice, G4; infected-JLP mice and treated with BNZ, G8; infected-Y mice and treated with BNZ. Data are expressed as mean \pm SD $p<0.05$ G3 vs. G4 and G7 vs. G8 

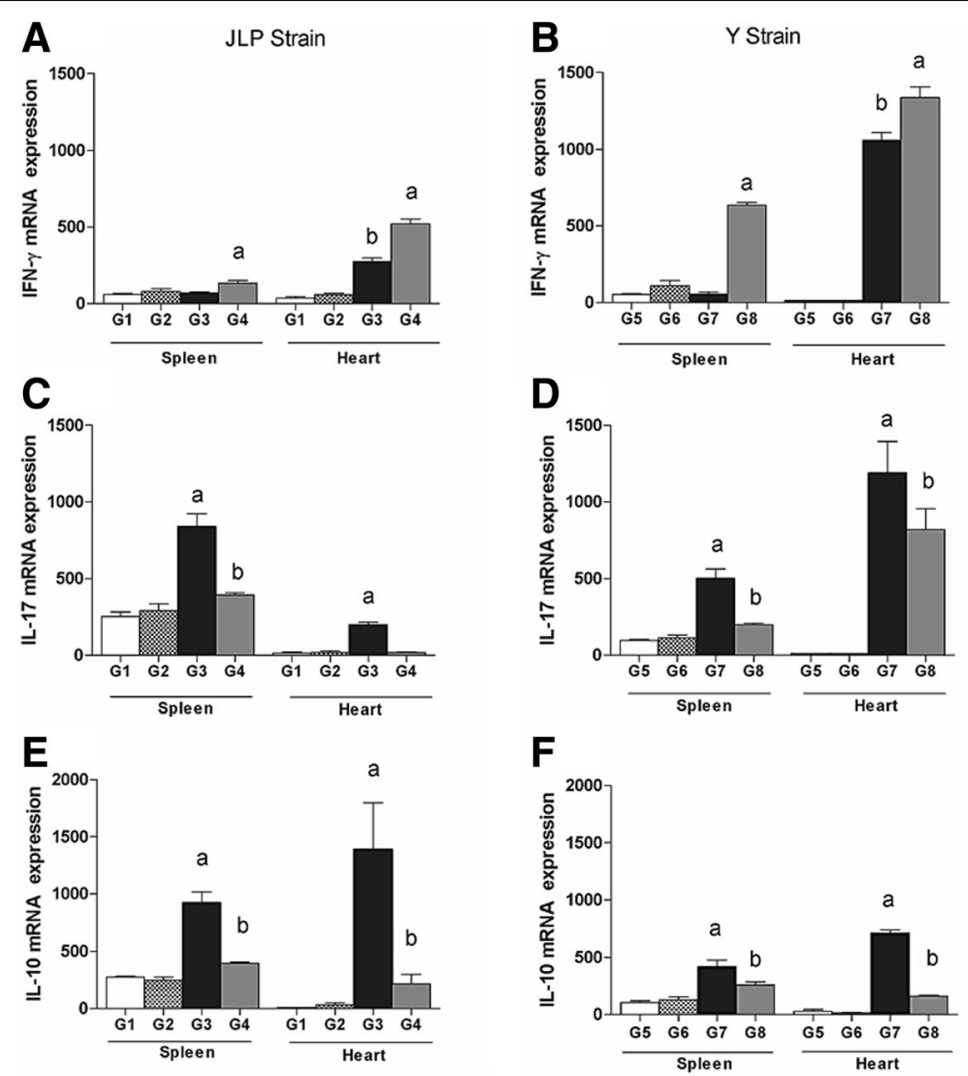

$\mathbf{F}$
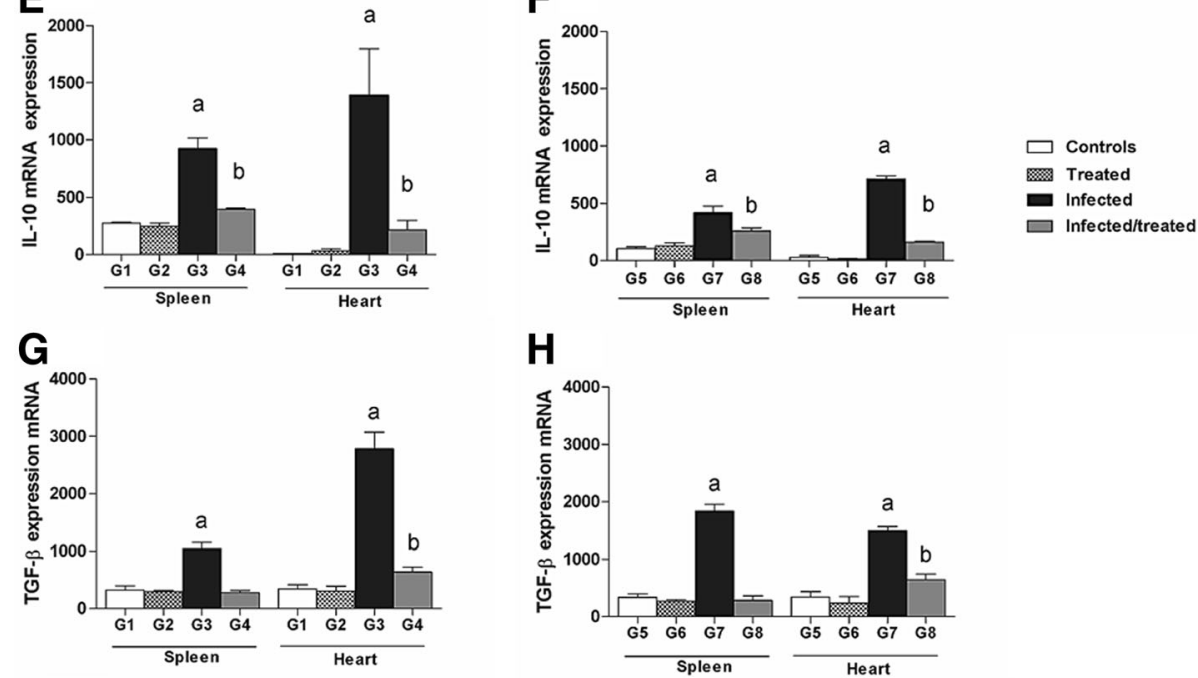

H
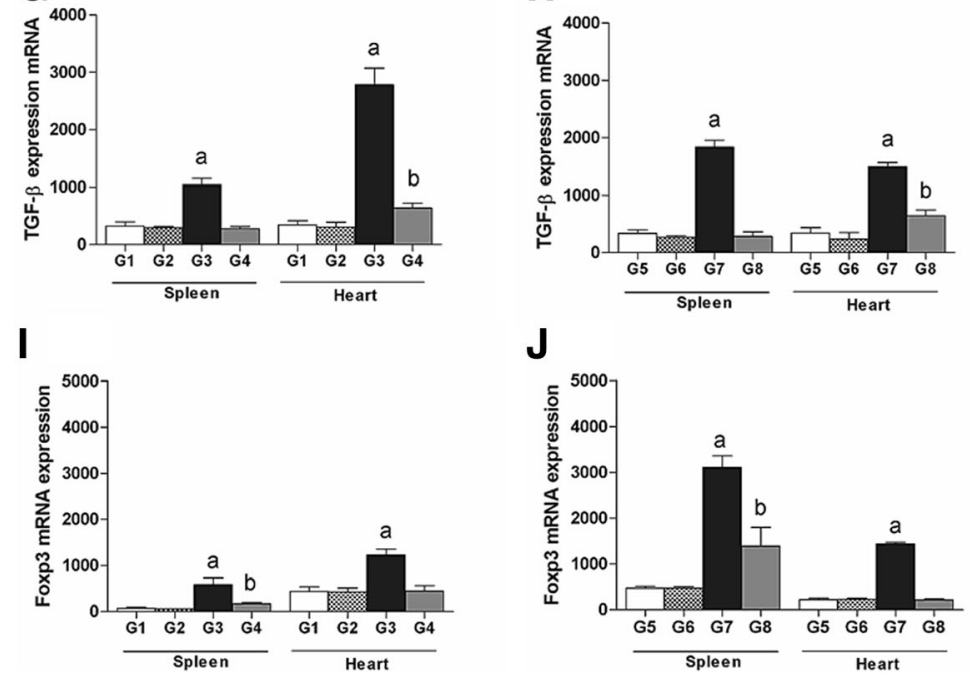

Fig. 2 mRNA expression of IFN- $\gamma$, IL-17, IL-10, TGF- $\beta$ and FoxP3. mRNA expression of IFN- $\gamma$, IL-17, IL-10, TGF- $\beta$ and FoxP3 in the spleen and heart of BALB/c mice $(n=5)$ during acute infection with $(\mathbf{a}, \mathbf{c}, \mathbf{e}) J L P$ and $(\mathbf{b}, \mathbf{d}, \mathbf{f})$ Y strains. G1, G5 - uninfected, untreated; G2, G6 - uninfected, BNZ-treated mice; G3, G7 - JLP-infected, untreated mice and Y-infected, untreated mice, respectively; G4, G8 - JLP-infected, BNZ-treated mice and Y-infected, BNZ-treated mice, respectively. Results are expressed as mean \pm SD. $p<0.05$. (a, b) a - G4 vs. G1, G2, G3 and G8 vs. G5, G6, G7; b G3 vs. G1, G2 and G7 vs. G5, G6. (c-j) a - G3 vs. G1, G2, G4 and G7 vs. G5, G6, G8; b G4 vs. G1, G2 and G8 vs. G5, G6

BNZ treatment decreases gene expression of IL-17, IL-10, TGF- $\beta$ and Foxp3 mRNA

The respective treatment effects on IL-17, L-10, TGF- $\beta$ and Foxp3 expression in the spleen and heart of animals infected with the Y or JLP strain are shown in Fig. 2. As to JLP and Y, the IL-17 expression did not differ between controls (G1, G5) and treated groups $(G 2, G 6)$ in the spleen or heart. Infection with JLP (G3) strain significantly increased IL-17 mRNA expression in both spleen (2.7-fold) and heart (11.6-fold) in relation to other 
groups. Infection with Y strain (G7) significantly increased IL-17 expression in spleen and heart (3.6-fold and 4.33-fold, respectively) in comparasion to other groups (Fig. 2c and d). Infected/treated groups presented significantly decreased IL-17 mRNA in spleen (G4: 2.14fold and G8: 2.52-fold) and heart (G4: 11.3-fold and G8: 1.45 -fold) compared to infected groups (G3, G7). However, except for the heart in JLP strain, infected/treated groups showed higher IL-17 expression $(p<0.05)$ than control and treated groups (Fig. $2 \mathrm{c}$ and $\mathrm{d}$ ).

We evaluated the effect of treatment with BNZ in IL-10, TGF- $\beta$ and Foxp3 gene expression during the acute phase of infection. No significant differences were found in expression of IL-10, TGF- $\beta$ and Foxp3 between control and treated groups (G1, G2 and G5, G6) in the studied organs. Mice infected with JLP strain (G3) showed significantly increased expression of IL-10, TGF- $\beta$ and Foxp3 in spleen (3-fold, 3.5-fold and 5.8-fold, respectively) and heart (16fold, 6.4-fold and 2.78-fold, respectively) compared to all other groups. Treatment in animals infected with JLP strain (G4) decreased significantly mRNA expression of IL-10, TGF- $\beta$ and Foxp3 in spleen (2.33-fold, 3.76-fold and 3.5 -fold, respectively) and heart tissues (6.43-fold, 4.38-fold and 2.73-fold, respectively) compared to infected groups (G3) (Fig. 2e-l).

Mice infected with Y strain (G7) showed significantly increased expression of IL-10, TGF- $\beta$ and Foxp3 in spleen (2.55-fold, 6.2-fold and 4-fold, respectively) and heart (10.7-fold, 3.65-fold and 6.43-fold, respectively) compared to all other groups. Treatment with BNZ in mice infected with $Y$ strain (G8) decreased significantly mRNA expression of IL-10, TGF- $\beta$ and Foxp3 in spleen (1.62-fold, 6.51-fold and 2.24-fold respectively) and heart (4.39-fold, 2.31-fold and 6.73-fold) in relation to infected groups (G7) (Fig. 2f-j). However, IL-10, TGF- $\beta$ and Foxp3 expression in infected/treated groups, with exception of TGF- $\beta$ in the spleen (Fig. 2g, h) and Foxp3 in the heart (Fig. 2l, j), the mRNA expression remained higher $(p<0.05)$ in relation to control and treated groups.

\section{Discussion}

BNZ has a cure rate of $86 \%$ in the acute phase of the disease, but only $8 \%$ in the chronic phase [39]. BNZ interferes in the synthesis of DNA, lipids and proteins of the parasites, facilitating their elimination [32]. Nevertheless, samples of T. cruzi naturally resistant to this drug could explain the low cure rate in some treated patients [40]. However, some studies report that activation of the immune system of the host seems to potentiate BNZ treatment efficacy in $T$. cruzi infection [16, 17, 34].

Our results show that treatment with BNZ in BALB/C mice with acute infection caused by the JLP or Y strain induced a significant reduction of parasites in the spleen and heart compared to infected animals that received no treatment. These results are in agreement with other experimental studies [41, 42]. It was observed that the number of parasites was considerably lower in JLPinfected than in Y-infected mice; and that the treatment led to the complete elimination of the parasite from the JLP strain. This difference may be because these strains of $T$. cruzi belong to different biodemes. The $\mathrm{Y}$ strain is characterized by a rapid multiplication and infection with high parasitemia, whereas the JLP strain seems to have slower multiplication and a later parasitemia peak $[42,43]$. In addition, the different strains of $T$. cruzi presents variable behaviors, due to their distinct genetic and biological characteristics, which promote differences in virulence, tissue tropism, BNZ resistance and treatment efficacy [14, 44]. Moreover, distinct genetic characteristics of the host and parasite may be associated with different clinical forms of the disease $[6,14,15]$.

In relation to IFN- $\gamma$, we observed that the heart of mice infected with $Y$ and JLP strains presented greater IFN- $\gamma$ expression in relation to uninfected groups. IFN- $\gamma$ production in the early stages of $\mathrm{CD}$ is responsible for activating macrophages to produce reactive oxygen, thus inhibiting parasite replication $[18,20$, $33,45,46]$. T. cruzi in the myocardium triggers the immune response of type Th1. NK cells and T. cruzispecific $\mathrm{T}$ lymphocytes migrate to heart and produce IFN- $\gamma$ [47-49]. However, our results showed that in the spleen, IFN- $\gamma$ expression did not differ between uninfected mice and those infected/untreated. Spleen cells produce low IFN- $\gamma$ levels in early stages of infection, possibly due to low IL-12 production and low NK cells activity [50].

BZN alters immune response in acute phase and elicits the production of IFN- $\gamma$ and possible differentiation of Th1 since our results demonstrated that treatment increased the mRNA expression of IFN- $\gamma$ in infected groups, which is consistent with other studies that showed higher levels of IFN- $\gamma$ after treatment [51]. On the other hand, a report showed that BNZ does not affect the production of IFN- $\gamma$ in the serum of mice infected with the Y strain [41]. It is known that the most effective treatment and parasitological cure for the $T$. cruzi infection is associated with initial production of inflammatory cytokines in early stages of infection [19, 33, 51-54] The BNZ induces clearence of the parasite and triggers the release of antigens, which increases the production of IFN- $\gamma$ and therefore enhances the action of the BNZ [55]. Production of IFN- $\gamma$ probably has restored the immune response of type-Th1, leading to the decreas of parasites in tissue.

This study evaluated the effect of treatment on the IL-17 expression in experimental infection with either one of two $T$. cruzi strains of different virulences. IL- 
17 plays a crucial role in resistance to infection and absence of this cytokine in mice has increased $T$. cruzi in the liver, heart and kidney and decreased inflammatory cytokines such as IFN- $\gamma$, TNF- $\alpha$ and IL-6 [22]. Other studies have shown the importance of IL17 in control of inflammation, in resolution of infection and parasite elimination [23, 56-58]. However, this citokine has been associated with inflammatory response and mortality in mice infected with $T$. cruzi $[59,60]$. Our results indicate that in acute infection with the two strains, infected animals showed increased IL-17 expression, similarly to other studies [22, 23, 61, 62]. Further, higher levels of IL-17 were found in the heart in Y-strain infection compared to the JLP strain, probably due to the high parasite load and virulence of the $Y$ strain, which may have been responsible for the stimulation and infiltration of a greater number of IL-17-producing cells.

On the other hand, treatment diminished the expression of this cytokine followed by a reduction in parasite load in both strains and organs studied. Similarly, Monteiro et al. [60] showed that survival of T. cruzi-infected mice was inversely proportional to the production of this cytokine. The IL-17 showed correlation with parasitemia load in spleen and heart tissue, the elevation of IL-17 in infected animals did not decrease the parasitemia load in tissue. However, the BNZ treatment restored the IL17 produciton near to levels observed in control group, for both strains, suggesting non-involvement of IL-17 in protective mechanisms in this experimental model. The increase of IL-17 before treatment can balance the expression of IFN- $\gamma$, reforcing the decrease and favoring the parasite survival $[54,59]$.

Although several studies have shown the involvement of Treg cells in CD [28-30], the role of Tregs in CD treatment is poorly understood, mainly in the acute phase of the infection with distinct strains. In the acute phase, Tregs probably help to decrease parasitemia and balance inflammatory response [56, 63]. Understanding the role of Tregs could help to control the inflammatory response and tissue damage, to reduce the intense Th17 response and autoimune response observed in several infections [64, 65].

IL-10 e TGF- $\beta$ are regulatory cytokines that possesses the ability to decrease inflammatory cytokines and appears to be deleterious in the early infection. In this way, these cytokines have been associated with susceptibility to $T$. cruzi infection $[66,67]$. Our study showed that $T$. cruzi infection resulted in increased IL-10, TGF-beta and Foxp3 expression compared to controls. These results suggest that both strains of $T$. cruzi can induce Treg and cytokine production associated with this cells [63, 64].

The BNZ treatment decrease the expression of Foxp3, TGF-beta and IL-10. This decrease provokes IFN- $\gamma$ production and Th1 profile. This findings suggest an efficient immune response of Th1 profile during the acute phase of infection a role in reducing parasitemia and reducing cardiac lesion. The bias of BNZ to reduce the lesion could be due IL-17 production; inflammatory cytokines associated with severity of DC and increased of neutrophils in cardiac tissue. The inflammation observed and described in DC increased the risk of morbidity in DC [64].

Newborns with CD produce higher amounts of IL-10 and lower amounts of IFN- $\gamma$ than uninfected ones; and leukocytes of these patients fail to produce IFN- $\gamma$ in vitro $[68,69]$. According to our results, IL-10 significantly decreased after BNZ treatment, suggesting the involvement of this cytokine in mechanisms that suppress the immune response. Our results also suggest that IL10 could be acting on the IFN- $\gamma$ or other cytokines involved in protective mechanisms in infection with $T$. cruzi strains. The results also show that the two strains present the same response profile before and after treatment in the studied organs. Other studies showed that BNZ could modulate the synthesis of IL-10, altering the balance of cytokines and changing the course of infection $[33,70]$. The treatment decreased the IL-10 expression, which may have contributed to the elevated expression of IFN- $\gamma$ in infection with Y and JLP strains. However, another study showed that patients in the indeterminate phase, after undergoing the treatment with BNZ, presented a balanced immune response, with IFN$\gamma$ production by $\mathrm{NK}$ and $\mathrm{T} \mathrm{CD}^{+}$cells, conferring effective treatment, and IL-10 production by $\mathrm{CD} 4^{+}$cells, responsible for clearance of parasites but without causing tissue damage or other deleterious effects during infection [16].

\section{Conclusions}

Our results show that treatment with BNZ affects mRNA expression of IFN- $\gamma$, IL-17 and IL-10 in the acute phase of infection by different strains of $T$. cruzi in the spleen and heart. Although the strains respond similarly in relation to expression of these cytokines, the parasites of the $Y$ strain were not eliminated. These results suggest that in addition to the beneficial effects of BZN in trypanocidal activity, which may vary according to the virulence and other strain characteristics, this treatment also displays immunomodulatory activity during infection. Additional studies are required to better understand the impact of BNZ treatment on the immune system and Treg modulation in infection with Trypanosoma cruzi strains with different virulence, especially in relation to the initial interaction of the parasites with cellular receptors and production of pro- and anti-inflammatory mediators and Tregs. 


\section{Abbreviations}

BZN: Benznidazole; CD: Chagas disease; P.i.: Post-infection; Treg: Regulatory T cell

\section{Acknowledgments}

We greatly appreciate the support we have received from Dra. Sueli Aparecida Calvi (in memorian) concerning the scientific and methodological contribution during the conduction of this research.

\section{Funding}

The present study was supported by the Graduation Program of Tropical Diseases, Botucatu Medical School, UNESP, Brazil.

\section{Authors' contributions}

All authors contributed equally to this work, from the research design to the writing of the manuscript. All authors read and approved the final manuscript.

\section{Ethics approval and consent to participate}

The present study was approved by the Animal Ethics Committee of Botucatu Medical School - UNESP (protocol number: FMB-PE-85/2010, CEUA-854/10).

\section{Consent for publication}

Not applicable.

\section{Competing interests}

The authors declare that they have no competing interests.

\section{Publisher's Note}

Springer Nature remains neutral with regard to jurisdictional claims in published maps and institutional affiliations.

\section{Author details}

'Department of Tropical Diseases, Botucatu Medical School, São Paulo State University (UNESP - Univ Estadual Paulista), Av. Professor Mário Rubens Guimarães Montenegro, s/n, Distrito de Rubião Júnior, Botucatu 18.6186-87, SP, Brazil. ${ }^{2}$ Department of Microbiology and Immunology, Botucatu Biosciences Institute, São Paulo State University (UNESP - Univ Estadual Paulista), Botucatu, SP, Brazil. ${ }^{3}$ Department of Biological Sciences, School of Pharmaceutical Sciences, São Paulo State University (UNESP - Univ Estadual Paulista), Araraquara, SP, Brazil. ${ }^{4}$ Department of Immunology, University of Western São Paulo (Unoeste), Presidente Prudente, SP, Brazil.

\section{Received: 29 March 2017 Accepted: 24 November 2017}

Published online: 12 December 2017

\section{References}

1. WHO. Chagas disease (American trypanosomiasis). 2016. http://www.who. int/mediacentre/factsheets/fs340/en/. Accessed 15 Mar 2017.

2. WHO Expert Committee. Control of Chagas disease. World Health Organ Tech Rep Ser. 2002;905:i-vi, 1-109, back cover.

3. Pereira PCM, Navarro EC. Challenges and perspectives of Chagas disease: a review. J Venom Anim Toxins incl Trop Dis. 2013;19:34. https://doi.org/10. 1186/1678-9199-19-34

4. Pinheiro E, Brum-Soares L, Reis R, Cubides JC. Chagas disease: review of needs, neglect, and obstacles to treatment access in Latin America. Rev Soc Bras Med Trop. 2017;50(3):296-300.

5. Conners EE, Vinetz JM, Weeks JR, Brouwer KCA. Global systematic review of Chagas disease prevalence among migrants. Acta Trop. 2016;156:68-78.

6. Sosa-Estani S, Segura EL. Etiological treatment in patients infected by Trypanosoma cruzi: experiences in Argentina. Curr Opin Infect Dis. 2006;19(6):583-7.

7. Bafica A, Santiago HC, Goldszmid R, Ropert C, Gazzinelli RT, Sher A. Cutting edge: TLR9 and TLR2 signaling together account for MyD88-dependent control of parasitemia in Trypanosoma cruzi infection. J Immunol. 2006;177(6):3515-9.

8. Gutierrez FRS, Mineo TWP, Pavanelli WR, Guedes PMM, Silva JS. The effects of nitric oxide on the immune system during Trypanosoma cruzi infection. Mem Inst Oswaldo Cruz. 2009:104(Suppl 1):236-45.

9. Albareda MC, Laucella SA, Alvarez MG, Armenti AH, Bertochi G, Tarleton RL, et al. Trypanosoma cruzi modulates the profile of memory CD8+ T cells in chronic Chagas' disease patients. Int Immunol. 2006;18(3):465-71.

10. Sathler-Avelar R, Lemos EM, Reis DD, Medrano-Mercado N, Araújo-Jorge TC, Antas PRZ, et al. Phenotypic features of peripheral blood leucocytes during early stages of human infection with Trypanosoma cruzi. Scand J Immunol. 2003:58(6):655-63.

11. Vitelli-Avelar DM, Sathler-Avelar R, Massara RL, Borges JD, Lage PS, Lana M, et al. Are increased frequency of macrophage-like and natural killer (NK) cells, together with high levels of NKT and CD4+CD25high T cells balancing activated CD8+ T cells, the key to control Chagas' disease morbidity? Clin Exp Immunol. 2006;145(1):81-92.

12. Bonney KM, Engman DM. Chagas heart disease pathogenesis: one mechanism or many? Curr Mol Med. 2008;8(6):510-8.

13. da Silveira ABM, Correa-Oliveira R, Matsuyama H, de Oliveira EC, Neto SG, Luquetti $\mathrm{AO}$, et al. Decreased expression of IK channels in neurons from enteric nervous system is associated with the development of chagasic megacolon. Hum Pathol. 2008;39(9):1406-7.

14. Buscaglia CA, Di Noia JM. Trypanosoma cruzi clonal diversity and the epidemiology of Chagas' disease. Microbes Infect. 2003:5(5):419-27.

15. Dutra WO, Menezes CAS, Magalhães LMD, Gollob KJ. Immunoregulatory networks in human Chagas disease. Parasite Immunol. 2014;36(8):377-87.

16. Sathler-Avelar R, Vitelli-Avelar DM, Massara RL, Borges JD, Lana M, TeixeiraCarvalho A, et al. Benznidazole treatment during early-indeterminate Chagas' disease shifted the cytokine expression by innate and adaptive immunity cells toward a type 1-modulated immune profile. Scand Immunol. 2006:64(5):554-63.

17. Sathler-Avelar R, Vitelli-Avelar DM, Massara RL, de Lana M, Pinto Dias JC, Teixeira-Carvalho A, et al. Etiological treatment during early chronic indeterminate Chagas disease incites an activated status on innate and adaptive immunity associated with a type 1-modulated cytokine pattern. Microbes Infect. 2008;10(2):103-13.

18. Michailowsky V, Silva NM, Rocha CD, Vieira LQ, Lannes-Vieira J, Gazzinelli RT. Pivotal role of interleukin-12 and interferon-gamma axis in controlling tissue parasitism and inflammation in the heart and central nervous system during Trypanosoma cruzi infection. Am J Pathol. 2001;159(5):1723-33.

19. de Pinho RT, da Silva WS, de Castro Côrtes LM, Silva Vasconcelos d, Sousa P, de Araujo Soares RO, Alves CR. Production of MMP-9 and inflammatory cytokines by Trypanosoma cruzi-infected macrophages. Exp Parasitol. 2014;147:72-80.

20. Rezende-Oliveira K, Sarmento RR, Rodrigues V Jr. Production of cytokine and chemokines by human mononuclear cells and whole blood cells after infection with Trypanosoma cruzi. Rev Soc Bras Med Trop 2012;45(1):45-50.

21. Fuenmayor $\mathrm{C}$, Higuchi ML, Carrasco H, Parada H, Gutierrez P, Aiello V, et al. Acute Chagas' disease: immunohistochemical characteristics of T cell infiltrate and its relationship with T. cruzi parasitic antigens. Acta Cardiol. 2005;60(1):33-7.

22. Miyazaki Y, Hamano S, Wang S, Shimanoe Y, Iwakura Y, Yoshida H. IL-17 is necessary for host protection against acute-phase Trypanosoma cruzi infection. J Immunol. 2010;185(2):1150-7.

23. da Matta Guedes PM, Gutierrez FRS, Maia FL, Milanezi CM, Silva GK, Pavanelli WR, et al. IL-17 produced during Trypanosoma cruzi infection plays a central role in regulating parasite-induced myocarditis. PLoS Negl Trop Dis. 2010;4(2):e604.

24. Belkaid Y. Role of Foxp3-positive regulatory T cells during infection. Eur J Immunol. 2008;38(4):918-21.

25. de Araújo FF Vitelli-Avelar DM, Teixeira-Carvalho A, Antas PR, Assis Silva Gomes J, Sathler-Avelar R, et al. Regulatory T cells phenotype in different clinical forms of Chagas' disease. PLoS Negl Trop Dis. 2011:5(5):e992.

26. Piccirillo CA, Regulatory T. Cells in health and disease. Cytokine. 2008;43(3): 395-401.

27. Belkaid Y, Regulatory T. Cells and infection: a dangerous necessity. Nat Rev Immunol. 2007;7(11):875-88.

28. Araujo FF, Gomes JAS, Rocha MOC, Williams-Blangero S, Pinheiro VM, Morato MJF, et al. Potential role of $\mathrm{CD} 4+\mathrm{CD} 25 \mathrm{HIGH}$ regulatory T cells in morbidity in Chagas disease. Front Biosci. 2007;12:2797-806.

29. Sales PA, Golgher D, Oliveira RV, Vieira V, Arantes RME, Lannes-Vieira J, et al. The regulatory CD4+CD25+ T cells have a limited role on pathogenesis of infection with Trypanosoma cruzi. Microbes Infect. 2008;10(6):680-8.

30. Kotner J, Tarleton R. Endogenous CD4(+) CD25(+) regulatory T cells have a limited role in the control of Trypanosoma cruzi infection in mice. Infect Immun. 2007:75(2):861-9.

31. Duschak VG, Couto AS. An insight on targets and patented drugs for chemotherapy of Chagas disease. Recent Pat Antiinfect Drug Discov. 2007; 2(1):19-51.

32. Maya JD, Cassels BK, Iturriaga-Vásquez P, Ferreira J, Faúndez M, Galanti N, et al. Mode of action of natural and synthetic drugs against Trypanosoma cruzi and their interaction with the mammalian host. Comp Biochem Physiol A Mol Integr Physiol. 2007;146(4):601-20. 
33. Revelli S, Le Page C, Piaggio E, Wietzerbin J, Bottasso O. Benznidazole, a drug employed in the treatment of Chagas' disease, down-regulates the synthesis of nitrite and cytokines by murine stimulated macrophages. Clin Exp Immunol. 1999;118(2):271-7.

34. Sathler-Avelar R, Vitelli-Avelar DM, Elói-Santos SM, Gontijo ED, TeixeiraCarvalho A, Martins-Filho OA. Blood leukocytes from benznidazole-treated indeterminate chagas disease patients display an overall type-1-modulated cytokine profile upon short-term in vitro stimulation with Trypanosoma cruzi antigens. BMC Infect Dis. 2012;12:123.

35. Brener Z. Therapeutic activity and criterion of cure on mice experimentally infected with Trypanosoma cruzi. Rev Inst Med Trop São Paulo. 1962;4:389-96.

36. Oliveira LRC, Picka MCM, Nicolete VC, Calvi SA, Marcondes-Machado J. Organ tropism during the acute and chronic phases of Trypanosoma cruzi infection in BALB/C mice. J Venom Anim Toxins incl Trop Dis. 2012;18(1):3443. http://www.scielo.br/scielo.php?script=sci_arttext\&pid=S167891992012000100005

37. Larionov A, Krause A, Miller WA. Standard curve based method for relative real time PCR data processing. BMC Bioinformatics. 2005;6:62

38. Cezário GAG, de Oliveira LRC, Peresi E, Nicolete VC, Polettini J, de Lima CRG, et al. Analysis of the expression of toll-like receptors 2 and 4 and cytokine production during experimental Leishmania chagasi infection. Mem Inst Oswaldo Cruz. 2011;106(5):573-83.

39. Cancado JR. Long term evaluation of etiological treatment of chagas disease with benznidazole. Rev Inst Med Trop São Paulo. 2002:44(1):29-37.

40. Murta SM, Gazzinelli RT, Brener Z, Romanha AJ. Molecular characterization of susceptible and naturally resistant strains of Trypanosoma cruzi to benznidazole and nifurtimox. Mol Biochem Parasitol. 1998;93(2):203-14.

41. Olivieri BP. Cotta-de-Almeida V, Araújo-Jorge T. Benznidazole treatment following acute Trypanosoma cruzi infection triggers CD8+ T-cell expansion and promotes resistance to reinfection. Antimicrob Agents Chemother. 2002:46(12):3790-6.

42. Santos CD, Loria RM, Oliveira LGR, Kuehn CC, Toldo MPA, Albuquerque S, et al. Effects of dehydroepiandrosterone-sulfate (DHEA-S) and benznidazole treatments during acute infection of two different Trypanosoma cruzi strains. Immunobiology. 2010;215(12):980-6.

43. Bértoli M, Andó MH, De Ornelas Toledo MJ, De Araújo SM, Gomes ML. Infectivity for mice of Trypanosoma cruzi I and II strains isolated from different hosts. Parasitol Res. 2006;99(1):7-13.

44. Macedo AM, Machado CR, Oliveira RP, Pena SDJ. Trypanosoma cruzi: genetic structure of populations and relevance of genetic variability to the pathogenesis of chagas disease. Mem Inst Oswaldo Cruz. 2004;99(1):1-12.

45. Campos MA, Closel M, Valente EP, Cardoso JE, Akira S, Alvarez-Leite Jl, et al. Impaired production of proinflammatory cytokines and host resistance to acute infection with Trypanosoma cruzi in mice lacking functional myeloid differentiation factor 88. J Immunol. 2004;172(3):1711-8

46. Une C, Andersson J, Orn A. Role of IFN-alpha/beta and IL-12 in the activation of natural killer cells and interferon-gamma production during experimental infection with Trypanosoma cruzi. Clin Exp Immunol. 2003;134(2):195-201.

47. Martins GA, Campanelli AP, Silva RB, Tadokoro CE, Russo M, Cunha FQ, et al. CD28 is required for T cell activation and IFN-gamma production by CD4+ and CD8+ T cells in response to Trypanosoma cruzi infection. Microbes Infect. 2004;6(13):1133-44.

48. Sanoja C, Carbajosa S, Fresno M, Gironès N. Analysis of the dynamics of infiltrating $\mathrm{CD} 4(+) \mathrm{T}$ cell subsets in the heart during experimental Trypanosoma cruzi infection. PLoS One. 2013;8(6):e65820.

49. Marino APMP, da Silva A. Dos Santos P, pinto LM de O, Gazzinelli RT, Teixeira MM, et al. regulated on activation, normal T cell expressed and secreted (RANTES) antagonist (met-RANTES) controls the early phase of Trypanosoma cruzi-elicited myocarditis. Circulation. 2004;110(11):1443-9.

50. Antúnez MI, Cardoni RL. IL-12 and IFN-gamma production, and NK cell activity, in acute and chronic experimental Trypanosoma cruzi infections. Immunol Lett. 2000;71(2):103-9.

51. Bahia-Oliveira LM, Gomes JA, Cançado JR, Ferrari TC, Lemos EM, Luz ZM, et al. Immunological and clinical evaluation of chagasic patients subjected to chemotherapy during the acute phase of Trypanosoma cruzi infection 14-30 years ago. J Infect Dis. 2000;182(2):634-8.

52. Ferraz ML, Gazzinelli RT, Alves RO, Urbina JA, Romanha AJ. Absence of CD4+ T lymphocytes, CD8+ T lymphocytes, or B lymphocytes has different effects on the efficacy of posaconazole and benznidazole in treatment of experimental acute Trypanosoma cruzi infection. Antimicrob Agents Chemother. 2009:53(1):174-9.

53. Romanha AJ, Alves RO, Murta SMF, Silva JS, Ropert C, Gazzinelli RT. Experimental chemotherapy against Trypanosoma cruzi infection: essential role of endogenous interferon-gamma in mediating parasitologic cure. J Infect Dis. 2002;186(6):823-8.

54. Ferraz ML, Gazzinelli RT, Alves RO, Urbina JA, Romanha AJ. The antiTrypanosoma cruzi activity of posaconazole in a murine model of acute Chagas' disease is less dependent on gamma interferon than that of benznidazole. Antimicrob Agents Chemother. 2007;51(4):1359-64.

55. Albareda MC, Laucella SA. Modulation of Trypanosoma cruzi-specific T-cell responses after chemotherapy for chronic Chagas disease. Mem Inst Oswaldo Cruz. 2015;110(3):414-21.

56. Guedes PMM, Gutierrez FRS, Silva GK, Dellalibera-Joviliano R, Rodrigues GJ, Bendhack LM, et al. Deficient regulatory T cell activity and low frequency of IL-17-producing T cells correlate with the extent of cardiomyopathy in human Chagas' disease. PLoS Negl Trop Dis. 2012;6(4):e1630.

57. Cobb D, Hambright D, Smeltz RB. T-Bet-independent effects of IL-12 family cytokines on regulation of Th17 responses to experimental T. cruzi infection. J Leukoc Biol. 2010;88(5):965-71.

58. Cobb D, Smeltz RB. Regulation of proinflammatory Th17 responses during Trypanosoma cruzi infection by IL-12 family cytokines. J Immunol. 2012; 188(8):3766-73.

59. Korn T, Bettelli E, Oukka M, Kuchroo VK. IL-17 and Th17 cells. Annu Rev Immunol. 2009;27:485-517.

60. Monteiro AC, Schmitz V, Morrot A, de Arruda LB, Nagajyothi F, Granato A, et al. Bradykinin B2 receptors of dendritic cells, acting as sensors of kinins proteolytically released by Trypanosoma cruzi, are critical for the development of protective type-1 responses. PLoS Pathog. 2007;3(11):e185.

61. Guo S, Cobb D, Smeltz RB. T-Bet inhibits the in vivo differentiation of parasite-specific CD4+ Th17 cells in a T cell-intrinsic manner. J Immunol. 2009;182(10):6179-86.

62. Magalhães LMD, Viana A, Chiari E, Galvão LMC, Gollob KJ, Dutra WO. Differential activation of human monocytes and lymphocytes by distinct strains of Trypanosoma cruzi. PLoS Negl Trop Dis. 2015;9(7):e0003816.

63. Bonney KM, Taylor JM, Thorp EB, Epting CL, Engman DM. Depletion of regulatory $T$ cells decreases cardiac parasitosis and inflammation in experimental Chagas disease. Parasitol Res. 2015;114(3):1167-78.

64. Guedes PMM, de Andrade CM, Nunes DF, de Sena Pereira N, Queiroga TBD, Machado-Coelho GLL, et al. Inflammation enhances the risks of stroke and death in chronic chagas disease patients. PLoS Negl Trop Dis. 2016;10(4):e0004669.

65. González FB, Villar SR, Fernández Bussy R, Martin GH, Pérol L, Manarin R, et al. Immunoendocrine dysbalance during uncontrolled T. cruzi infection is associated with the acquisition of a Th-1-like phenotype by Foxp3(+) T cells. Brain Behav Immun. 2015;45:219-32.

66. Roffê E, Rothfuchs AG, Santiago HC, Marino APMP, Ribeiro-Gomes FL, Eckhaus $M$, et al. IL-10 limits parasite burden and protects against fatal myocarditis in a mouse model of Trypanosoma cruzi infection. J Immunol. 2012;188(2):649-60.

67. Silva JS, Twardzik DR, Reed SG. Regulation of Trypanosoma cruzi infections in vitro and in vivo by transforming growth factor beta (TGF-beta). J Exp Med. 1991;174(3):539-45.

68. Mayer JP, Biancardi M, Altcheh J, Freilij H, Weinke T, Liesenfeld O. Congenital infections with Trypanosoma cruzi or Toxoplasma gondii are associated with decreased serum concentrations of interferon- $y$ and interleukin-18 but increased concentrations of interleukin-10. Ann Trop Med Parasitol. 2010;104(6):485-92.

69. Vekemans J, Truyens C, Torrico F, Solano M, Torrico MC, Rodriguez P, et al. Maternal Trypanosoma cruzi infection upregulates capacity of uninfected neonate cells to produce pro- and anti-inflammatory cytokines. Infect Immun. 2000:68(9):5430-4.

70. Piaggio E, Roggero E, Pitashny M, Wietzerbin J, Bottasso OA, Revelli SS. Treatment with benznidazole and its immunomodulating effects on Trypanosoma cruzi-infected rats. Parasitol Res. 2001;87(7):539-47. 